doubt that the improved lattice theory will be able to explain all cases of Raman effect and other phenomena observed by the Indian physicists.

${ }^{t}$ Nature, 154, 782 (1944).

${ }^{2}$ Rossi and Regener, Phys. Rev., 58, 837 (1940).

'Jánossy and Rochester, Proc. Roy. Soc., A, 181, 399 (1943).

"Wathaghin, M. D. de Souza Santos, Pompeia, Phys. Rev., 5\%, 339 (1940).

5 Jánossy, Proc. Roy. Soc., A, 179, 361 (1941); Phys. Rev., 64, 345 (1943).

6 Hamilton, Heitler and Peng, Phys. Rev., 64, 78 (1943). Heitler, Proc. Irish Acad., A, 50, 155 (1945).

7 Jánossy, Rochester and Broadbent, Nature, 155, 142 (1945).

${ }^{8}$ Dirac, Proc. Roy. Soc., A, 183, 284 (1945).

'Heitler, Proc. Camb. Phil. Soc., 37, 291 (1941).

${ }^{10}$ Wilson, Proc. Camb. Phil. Soc., 37, 301 (1941).

1 Born, "Atomtheorie des Festen Zustandes" (Leipzig, 1923).

12 Ackermann, Ann. Phys., 46, 197 (1915).

${ }^{18}$ Boguslawski, Phys. Z., 15, 283, 569, 805 (1914).

14 Born, Z. Phys., 7, 217; 11, 327 (1921).

${ }^{15}$ Barnes, Z. Phys., 75, 723 (1932).

${ }^{16}$ Born and Blackman, Z. Phy8., 82, 551 (1933). Blackman, Z. Phys., 86, 421 (1933).

${ }^{17}$ Fermi and Rasetti, Z. Phys., 61, 598 (1930).

${ }^{18}$ Krishnan, Proc. Ind. Acad. Sci., 18, 298 (1943).

${ }^{19}$ Born and Bradburn-not yet published.

\section{THE ROYAL SCHOOL OF MINES}

\section{GEOLOGY, MINING AND METALLURGY AT THE IMPERIAL COLLEGE}

\section{BY PROF. W. R. JONES}

$\mathrm{T}$ OWARDS the middle of the last century, at the dawn of the industrial age, when the demand for machinery to quicken the pace of life was becoming more and more insistent, the value of the application of scientific knowledge to the many problems confronting Great Britain and the British Empire was becoming realized slowly but surely. In no sphere of activity was the need for such knowledge more marked than in increasing the supply of metals. The pressing demand for these necessitated the search by geologists for the minerals containing the metals; the working of the mineral deposits required mining engineers; and the extraction of the useful metals needed metallurgists. If rapid progress were to be made, it became manifest that the training of geologists, mining engineers and metallurgists was a matter of profound importance. It was the insistent demand for such training-not then available anywhere in the British Empire-that gave birth to what later became known as the Royal School of Mines.

At this period the Geological Survey had as its head Sir Henry de la Beche, a man of outstanding personality and vision who not only dominated the Survey but also wielded great influence with the Government. $\mathrm{He}$ had accumulated a large collection of minerals, geological maps, plans of mines and drawings of mining machinery which he housed at Craig's Court, adjoining Scotland Yard, London. This was opened to the public in 1841 as a Museum of Economic Geology to "exhibit the practical application of geology to the useful purposes of life". The exhibit aroused such great interest that the need for more accommodation caused the Government to erect a new building, and on May 12, 1851, the Museum of Practical Geology in Jermyn Street was opened by the Prince' Consort.

This gave de la Beche the opportunity he had long cherished of using the Museum and its collection for training in mining and applied science; and six months later, on November 6, he delivered the inaugural address as director of the Government School of Mines and Science applied to the Arts. In preparation for this new School, he had gathered around him a group of the most eminent men in their particular subjects: Warington W. Smyth for mining and mineralogy; Andrew C. Ramsay for geology and its practical application; John Percy, the 'father of English metallurgy'; Robert Hunt for mechanical science with its application to mining; Edward Forbes for natural history applied to geology and the arts; and Lyon Playfair-afterwards Lord Playfair-for chemistry applied to the arts and agriculture. It is an outstanding tribute to the genius of de la Beche in the selection of his staff that every member of this brilliant group became a fellow of the Royal Society and achieved international fame; and together they established for the School an unsurpassed reputation throughout the Empire.

After the death of Sir Henry de la Beche in 1855, Sir Roderick Impey Murchison, a virile leader, succeeded after many rebuffs in changing the title of the School in 1857 to the Government School of Mines, and in 1863 to the Royal School of Mines, the title which it still retains as one of the components of the Imperial College of Science and Technology. The School was transferred in $\mathbf{1 8 7 2}$ from Jermyn Street to the Royal College of Science (now the Huxley Building) in South Kensington, and, in 1913, to its nearby present home in Prince Consort Road.

The Royal School of Mines is essentially a teaching institution, fulfilling the purpose for which the Imperial College of Science and Technology was incorporated: "to give the highest specialised instruction, and to provide the fullest equipment for the most advanced training and research in various branches of science, especially in its application to industry". Its particular function is training in the application of the principles of science and engineering to the fundamental industries of mining, metallurgy, and oil.

\section{Geology}

From the initial stages of the School, the Geology Department has been closely linked with the Mining and Metallurgy Departments, and with the passage of time this link has become more strongly forged, for now the three departments are housed together in the Royal School of Mines. Two thirds of the students of the Department receive the associateship of the School; the remaining third, studying pure geology, belong to the Royal College of Science. During the last twenty years almost all the students attending the School in any of its departments sit also for the Honours B.Sc. of the University of London.

Sir Henry de la Beche, the founder of the School, Sir Roderick Murchison, his successor as its director and head of the Geological Survey, and Sir Andrew Ramsay, its first professor of geology (1856-76), were all eminent geologists, who played a great part in laying the sure foundations of their science and in building upon them its broad developments. Their achievements have become incorporated in the body of the science.

Advances in geology are rarely spectacular; it is more a case of "precept upon precept, line upon line, here a little, and there a little". 'The Geology Department can look back with satisfaction on a century of productive research in all branches of the subject. 
Judd (1878-1905), who succeeded Ramsay, made sound contributions to the Jurassic and Cretaceous stratigraphy of Great Britain, and the results of his investigations into the complexities of the Tertiary vulcanicity of the Hebrides are of signal merit. It has been truly stated of him that he established the "first thorough course of practical instruction in geology established in Britain, and perhaps in the world". He trained a group of practical geologists who have made their mark on geological science in all parts of the world-a group containing Boulton, Grenville Cole, Hume, Sir Thomas Holland, Skeats, Cullis, Tyrrell, Morley Davies, Rutley, Sherlock and many others is no mean memorial.

Judd was followed by W. W. Watts, who occupied the chair during 1905-30. His contributions to the stratigraphy and petrology of Shropshire and the Midlands remain of fundamental importance to the geology of Britain. Invaluable also have been his services to the science as its counsellor. Building upon the foundations of his predecessors, he expanded the departmental courses to keep abreast of progress, and in his teaching he inspired his students and colleagues to undertake research work in various branches of geology. Under his guidance, two new sub-departments were instituted to supply men trained for special work in the oil and mining industries. That in oil technology, comprising geology, surveying and engineering was established in 1912 ; and under the direction of Prof. V. C. Illing it has prospered exceedingly and has supplied fully trained men to oil companies in various parts of the world. The second special training is in mining geology, which includes in addition to geology, surveying, assaying and the principles and economics of mining. This training was fostered by Prof. C. G. Cullis with such success that the demand for graduates in mining geology has always been greater than the supply. Cullis was followed in the chair by W. R. Jones, its present occupant.

Under Watts there thus began the production of highly trained practical geologists, many of whom now hold chairs in British universities, are members of the Geological Survey, directors of Colonial Geological Surveys or consultants to mining and oil companies. A roll of the distinguished old students and colleagues of Watts would include Boswell, Bracewell, Brammall, Bulman, Dewhurst, Eastwood, Broughton Edge, Fitch, Hitchin, Holmes, Ingham, Jones, Lepper, Read, Edmondson Spencer, Stubblefield, Wade, Wayland, Whitehead, Whittard and many more.

In this way, the Geology Department of the Royal School of Mines, like those of Mining and Metallurgy, has made a very great contribution to Colonial and Imperial development, and can justly consider itself a worthy part of an Imperial College. While a most important function of the Department is this training of high-class geological technicians for the oil and mining industries, just as important a function is the provision of postgraduate training, especially for Dominion, Colonial, Indian and foreign graduates. On many occasions, the student population of the postgraduate school of the Geology Department has been made up of men from a dozen countries.

Watts was succeeded by Prof. P. G. H. Boswell, who continued the development of the postgraduate school and himself established much of the basis of modern sedimentary petrology following his important work on British glass- and moulding-sands. In 1939, Boswell retired for health reasons and was followed by the present head of the Geology Department, Prof. H. H. Read. The codification of views upon granitization and its relation to metamorphism have been the subject of three presidential addresses by Read, and his far-reaching proposals for a genetic classification of rocks are widely acknowledged to merit careful consideration.

Among researches carried out in the Department during the last decade may be mentioned those of Illing on oil geology, Hobson on the compaction of sediments and the properties of clay suspensions, Wood on the algæ, Jones, Brammall and Leech on the etiology of industrial dust diseases, Brammall and Leech on metamorphic granitization as developed in Dartmoor and the Malverns, and many more.

The chief contributions to the advance of geology during the last century from the Geology Department. have thus been the establishment of the basic principles, a large output of competent original work, a great production of trained men especially in oil and mining geology fitted for service abroad, and the formation of a strong and varied postgraduate school which attracts students from all parts of the British Empire and from foreign countries.

\section{Mining}

The progress during the century in underground activities is no less important, though less known, than that of surface transport from the days of the stage-coach to the most modern motor-car. Especially is this so in the type of mining with which the Royal School of Mines is concerned. Hand-drilling has been replaced by pneumatic-drilling, gunpowder by gelignite and other highly efficient and safer explosives, hand-loading by mechanical scrapers ; transport from the working-face of the broken ground is no longer by man-power but by mechanical traction, horsewhins for raising the naterial to the surface have given place to power winding-machinery, pits of a maximum depth of a few hundred feet have become shafts thousands of feet in depth, and ventilation arrangements of the crudest kind have been replaced by well-planned systems employing large fans of high efficiency, aided, in the deepest and hottest minessome of which are more than a mile and a half below the surface--by refrigerating plants. These are some, but not all, of the great improvements in the art of mining during the last few decades.

Concerning all these advances, the Mining Department of the School has been and still is the premier place in the British Empire for the training of the mining engineers who, in co-operation with other engineers in their different spheres, have made such progress possible.

The Department was particularly fortunate in its first professor, Sir Warington Smyth. On leaving Cambridge, Smyth spent four years on the mining fields of Europe and the Near East, advising mining companies and collecting representative samples of minerals and rocks from those fields. On his return, he joined the staff of the Geological Survey, became chief mineral inspector of the Office of Works and of the Duchy of Cornwall and adviser to the Crown on all mining matters. His knowledge of geology, and of its practical application to mining, formed the basis on which he built the mining course at the School. Since his day the subjects forming the course have increased considerably in scope with the progress of science; but during the hundred years that have elapsed, the principles of geology have remained 
a fundamental part of the training of the mining engineer.

Smyth was followed in the chair by Clement le Neve Foster, Herbert Cox, William Frecheville and S. J. Truscott, all men of great eminence in the mining industry before they accepted the professorship. They were able to present to their students first-hand information concerning the mining problems of their day and the improvements they visualized in the future, thus to inspire their hearers to keep abreast of their subject and to retain the international reputation of their forerunners. The standard of athletic prowess set by the first head of the Mining Department-a Rowing Blue-has been maintained by the present head, Prof. J. A. S. Ritson, a former English International Rugby player.

Progress in mining is achieved in the mines, not in college laboratories. Some practical improvement in the art of mining is of almost daily occurrence ; and although this is the fruit of research, it is not of the kind that results in the publishing of scientific papers. Thus it is that the strength of the Department lies in its training to bring about these useful practical improvements in the mines rather than in research work carried out within its doors.

In fulfilling this, its most important function, it has been very successful. The excellence of its training has attracted students from all parts of the British Empire. The Department is unique in the number of awards granted to its past students by professional mining institutions, and in the positions of highest responsibility in the mining world occupied by its alumni. The A.R.S.M., the diploma awarded to its students, has an unsurpassed reputation in the Dominions and the Colonies, where almost all its students go on leaving the School; and the demand by the Colonial Governments and mining companies for those trained in the Department has always been. greater than the supply. Particularly is this so during the past few years, when only a small fraction of the posts offered could be fulfilled.

\section{Metallurgy}

The first English text-book on metallurgy was written by Dr. John Percy, the first professor of metallurgy at the Government School of Mines and of Science applied to the Arts, later to be known as the Royal School of Mines. Percy has been truly described as the 'father of English metallurgy', and it could well be stated that for the first decade of his professorship, his department was the cradle in which British metallurgy was nurtured. Among the results of his many successful researches was the adoption for the Patera process in 1858 using sodium thiosulphate for the leaching of silver ores.

In those early days, phosphoric iron deposits remained useless as a source of iron, for no method was known by which the deleterious phosphorus could be removed. Percy Carlyle Gilchrist, in association with his cousin Sidney Gilchrist Thomas, and inspired by John Percy, carried out experiments which ultimately established the basic Bessemer process for converting phosphoric pig iron into good-grade steel. The first patent was taken out in 1877 and from it was developed the modern basie steel industry.

Percy was professor during 1851-80, and was followed by Sir William Chandler Roberts-Austen (1880-1902), an exceptionally able and inspiring teacher, who fostered the growth of physical metallurgy-then in its babyhood-to such a degree that his team of researchers, which included D. G.
Bengough, O. F. Hudson, W. H. Merrett and A. Stansfield, made notable advances in the study of metallography.

William Gowland, then a well-known authority on the metallurgy of copper, followed Roberts-Austen and was professor during 1902-9. He completed the Fifth Alloys Research report, the first four having been published by his predecessor.

For the five following years, 1909-13, the chair was occupied by William A. Carlyle, who had been manager of Rio Tinto Mines and smelter. His wide experience in industry enabled him to impress on his students the importance of understanding practical operations on a large scale.

Sir Henry Cort Harold Carpenter was professor from 1913 until his tragic death in 1940. Under his direction, considerable advances were made in the study of corrosion of metals and, in collaboration with Miss Elam (Mrs. Tipper), the first sirgle crystals of aluminium were produced, thereby providing data which have proved of fundamental importance. As chairman of a large number of Government commissions and research institutions, he was able to exercise great influence in promoting the advancement of knowledge in a wide variety of metallurgical operations.

In the course of the century, the Department has produced many metallurgists of outstanding $\epsilon$ minence, and professors who, in their turn, have grafted on their universities the courses initiated at their Alma Mater. Among its brilliant students were C. $\mathrm{O}$. Bannister, C. V. Boys, A. J. Brett, A. C. Claudet, Sir Lewis Fermor, P. C. Gilchrist, F. W. Harbord, O. F. Hudson, W. F. Hume, Henry Louis, A. McCance, B. McNeill, T. A. Rickard, E. Riley, Sir Thomas Rose, S. W. Smith, A. Stansfield, T. Turner, and E. A. Wraight.

The Royal School of Mines, proud of its achievements, is beginning its second century in a spirit of high endeavour, fully confident that it will continue to produce the highly trained geologists, mining engineers and metallurgists who during peace and war have served Britain and the British Empire with conspicuous success.

\section{THE ALLIED PLAN FOR EDUCATION}

\section{By DR. E. F. ARMSTRONG, F.R.S.}

$\mathrm{T}$ HE United Nations Educational, Scientific and Cultural Organisation (U.N.E.S.C.O.) commenced its deliberations in London on November 1 and was able to have its constitution agreed and signed by the representatives of forty-four nations on November 16. The principal object of this Conference was to draw up the constitution of the new body; the delegates attended primarily, therefore, in a diplomatic rather than an educational capacity.

Perhaps the outstanding achievement to many of us is the inclusion of the word 'Scientific' in the title as well as in all pertinent places in the text. Science has now world recognition as an equal partner in the great task of world educational reconstruction.

It is generally recognized that the failure to set up an educational body on the same lines as the International Labour Office after the First World War was a serious omission. The remarks of the 